University of Nebraska - Lincoln

DigitalCommons@University of Nebraska - Lincoln

Sociology Department, Faculty Publications

Sociology, Department of

2005

Individual, Congregational, and Denominational Effects on Church

Members' Civic Participation

Philip Schwadel

University of Nebraska-Lincoln, pschwadel2@unl.edu

Follow this and additional works at: https://digitalcommons.unl.edu/sociologyfacpub

Part of the Sociology Commons

Schwadel, Philip, "Individual, Congregational, and Denominational Effects on Church Members' Civic Participation" (2005). Sociology Department, Faculty Publications. 83.

https://digitalcommons.unl.edu/sociologyfacpub/83

This Article is brought to you for free and open access by the Sociology, Department of at DigitalCommons@University of Nebraska - Lincoln. It has been accepted for inclusion in Sociology Department, Faculty Publications by an authorized administrator of DigitalCommons@University of Nebraska - Lincoln. 


\title{
Individual, Congregational, and Denominational Effects on Church Members' Civic Participation
}

\author{
Philip Schwadel \\ Department of Sociology, University of Nebraska-Lincoln
}

\begin{abstract}
Previous research demonstrates two aspects of religion that affect civic activity - church participation and religious conservatism. Conservative religious beliefs and membership in conservative denominations are often associated with low levels of civic activity while church participation is said to increase civic activity. This article advances the discussion of the relationship between religion and civic participation by introducing the congregational context. Data from the 1987 Church and Community Planning Inventory show that congregations vary in their members' civic activity - congregational factors associated with conservative Christianity (high levels of biblical literalism and within-church friendships) are strongly and negatively associated with church members' activity in nonchurch organizations. At the individual level, the data show that education and participation in church activities other than religious services have particularly strong, positive effects on church members' activity in nonchurch organizations. The findings demonstrate that a conservative congregational context limits church members' activity in nonchurch organizations, potentially limiting their opportunities to build heterogeneous social networks and social capital that bridges church members to other people in their communities.
\end{abstract}

\section{Introduction}

Most social networks are demographically homogeneous, meaning people generally interact with those like themselves (Popielarz 1999). This is in large part due to the fact that most organizations, neighborhoods, and even churches are highly homogeneous (Dougherty 2003; McPherson 2001). Churches that take up much of their members' time and discourage many forms of contact with secular society can restrict interactions among demographically diverse people, particularly between people within the church and those outside of the church (Campbell 2004). Churches can limit network heterogeneity and thus limit the opportunity for bridging social capital, a vital form of capital for the exchange of resources across demographically diverse groups, by discouraging members from participating in secular organizations.

Conversely, churches can also offer a rare and important opportunity to create more heterogeneous networks and the possibility of bridging social capital by encouraging members to participate in extra-church activities, whether through religious ideology, sharing information on opportunities for activities outside of the church, or encouraging civic activity through civic skill education (Verba, Schlozman, and Brady 1995; Wood and Warren 2002). Religious participation and religious beliefs that contribute to civic activity are essential for the spread of resources and ideas. This article introduces the congregation into the relationship between religion and civic participation, demonstrating the effects of the conservative congregational context in limiting church members' civic activities that can increase network heterogeneity and possibly provide crucial forms of bridging social capital.

Conservative Christians are generally less likely to participate in secular organizations than their liberal or mainline counterparts (Casanova 1994; Iannaccone 1988; Smidt 1999; Wuthnow 1999). On the other hand, Americans who are active in religious organizations tend to be more likely to participate in civic organizations than those who are less religiously active (Lenski 1963; McIntosh and Alston 1982; Smidt 1999). Research on the subject of religion and civic par- 
ticipation has traditionally focused on denominational differences in civic participation, showing the greater tendency of Christians from mainline denominations, compared to Christians from conservative denominations, to participate in secular activities (e.g., Marx 1967; Pope 1942).Without abandoning the relationship between denominational affiliation and civic participation, more recent research has noted the effects of individual religious ideology and activity on civic participation and secular activities (e.g., Kellstedt and Smidt 1993; Peterson 1992; Regnerus and Smith 1998).

While most religious research focuses on denominations and individual ideology and activity, the congregation is the locus of religious activity for American Christianity (White 1968). The congregation, not the denomination, is the social context of the Christian religion in the United States. Christians do not interpret their religion in a vacuum; they take cues from fellow parishioners and clergy (Wald, Owen, and Hill 1990). The congregational context influences church members' activities within the church and their views of social action outside of the church (Kanagy 1992; Schwadel 2002). Given the importance of the congregation in American Christianity, congregational influences may play as great a role as denominational and individual religious factors in affecting church members' secular activity and civic participation. The context of conservative theology, where church members as a group come to understand the meaning of their theological outlooks, is particularly likely to affect church members' views of the world. This article extends research on the relationship between religion and civic participation by demonstrating the effect of conservative congregational contexts on church members' participation in civic organizations.

\section{Religion and Civic Activity}

Two aspects of religion are regularly shown to influence civic activity. First, church participation increases civic activity through enhanced social capital, such as civic skills and communication networks. Researchers often highlight the positive relationship between church participation and civic participation (e.g., Park and Smith 2000; Peterson 1992). In his influential book The Religious Factor (1963:247), Lenski showed how the church operates as a "training ground" for Protestants to participate in secular voluntary organizations. More recently, Verba and colleagues (1995:282) pointed out that "[r]eligious institutions are the source of significant civic skills, which, in turn, foster political activity." In addition to the skills developed in church activities, social capital research suggests that religious organizations foster secular volunteering through informational networks. Greeley (1997), for example, showed that people often learn about secular volunteering opportunities from religious sources; and, as the social movement literature demonstrates, hearing about opportunities for voluntary activity and being influenced to participate by friends, such as fellow church members, are often the most important predictors of voluntary activity (Klandermans and Oegema 1987; McAdam and Paulsen 1993). It is important to note that church activities other than religious service attendance are pivotal to this relationship between religious activity and civic activity. Church activities other than attending services may provide vital civic skills and the opportunity for church members to learn about occasions for civic participation, while simply attending religious services may not bring the same benefits (Lam 2002).

The second effect of religion on civic participation concerns the generally lower levels of secular participation among conservative or evangelical Christians compared to liberal or mainline Christians (Finke and Stark 1992; Iannaccone 1988; Wuthnow 1988; for exceptions, see Regnerus and Smith 1998; Smith 1998). It is not that conservative Christians are not at all civically active; rather, they tend to participate in civic activities within the church instead of outside of the church (Wuthnow 1999). Studies of the effects of conservative Christianity on civic participation generally measure conservatism and liberalism through denominational affiliation or personal beliefs. Empirical researchers devote much attention to dividing denominations into separate theological and practical groupings (e.g., Steensland et al. 2001). Although historically contingent, differ- 
ent denominations promote different views of secular society and civic activity (for discussions of the historic role of denominationalism, see Ammerman 2000; Niebuhr 1929; Wuthnow 1988). When it comes to individual indicators, biblical literalism, an emphasis on conversion, and a personal relationship with Jesus Christ are important and often used as measures of conservative Christianity (Woodberry and Smith 1998). Holding conservative beliefs or belonging to a conservative denomination can lead Christians to shun many forms of civic participation, though certainly not all. Some conservative beliefs and certain denominations may influence Christians to devote much of their energies to saving souls, their own souls and others' souls, rather than participating in secular organizations (Wuthnow 1988).

\section{The Congregational Context}

Although conservative individual beliefs and affiliation with a conservative denomination are negatively associated with civic participation, this article argues that the congregation is a major component of the relationship between conservative Christianity and civic participation. Clergy and fellow parishioners affect congregation members' opinions and actions. Research shows that congregational affiliation is often as strongly, or more strongly, correlated with social and political outcomes than are individual religious beliefs (e.g., Gilbert 1993; Jelen 1993; Wald, Owen, and Hill 1988, 1989, 1990). Although much research shows that conservative Christians are less likely than liberal Christians to participate in civic organizations, it is not clear whether it is Christians with conservative beliefs, those from conservative denominations, or members of conservative congregations that are prone to be less participatory in civic activities. The negative effect of conservative Christianity on civic activity should be contingent on the congregational context, given that a church member's understanding of what it means to be a conservative Christian is influenced by his or her church. While the congregational context is important, denominational affiliation may often act as a proxy for the congregational context in much research, since congregations within denominations tend to be somewhat similar.

Organizational closure arguments suggest that conservative congregations limit members' nonchurch activity. In fact, Iannaccone $(1988,1994)$ suggests that organizational closure is the hallmark of conservative Christianity. A conservative church, according to Iannaccone, is defined as one that limits members' participation in many forms of secular activity and increases members' activity within the church. The organizational closure argument suggests that people who are active in conservative congregations are less active in secular organizations because they spend a large proportion of their time participating in religious activities. Iannaccone's organizational model stresses how conservative congregations weed out free riders, thereby ensuring an active congregation, but one with members who do not have much time for nonreligious organizational participation.

Similarly, Smith (1998) demonstrates how the strength of modern-day evangelicalism comes from subcultural identities, where evangelicals draw clear distinctions between themselves and other groups, particularly secular society, thereby creating strong within-group ties. The high rate of internal friendships and organizational closure in conservative congregations is not a new idea in sociology (e.g., Demerath 1965). All organizations compete for members and resources, but "active membership" organizations, such as conservative congregations, require more time and resources from their members and thus have a greater effect on members' other organizational commitments (McPherson and Rotolo 1996).

In addition to the organizational closure of conservative congregations, the context of conservative theology, which can lead church members to focus more on saving souls and less on secular participation, may influence civic activity. Previous research shows that conservative theology, specifically a literal view of the Bible, leads to low levels of civic participation (e.g., Kanagy 1992). Regardless of an individual church member's theological outlook, however, a conservative theological context may lead him or her to behave in manners consistent with those who hold 
conservative beliefs. There is a contagion effect in churches, where the views of church members and church leaders influence other members' actions and beliefs (Gilbert 1993). ${ }^{1}$ Where there is a general atmosphere of conservative Christianity in the church, all members may also be influenced to be less active outside of the church. The atmosphere of conservative theology that stresses saving souls, in combination with the organizational closure associated with conservative congregations, suggest that membership in a conservative congregation leads to lower levels of civic activity.

The positive effects of church activity on civic participation, the negative effects of conservative theology and organizational closure on civic participation, and the importance of the congregational context suggest four hypotheses concerning the effects of religion on civic participation. First, church members who hold conservative religious beliefs and who have many within-church social ties are less civically active than Christians who are less theologically conservative and who have fewer within-church social ties. Second, church members who are active in church organizations are more civically active than the church members who are less participatory or do not participate at all in church organizations. Third, members of theologically conservative congregations, and congregations with many within-church social ties, are less civically active than members of less conservative congregations and congregations with fewer within-church social ties. Fourth, the relationship between denominational affiliation and civic activity is largely a proxy for the relationship between the congregational context and civic activity, meaning denominational effects on civic activity will diminish with the addition of congregational characteristics to the model.

\section{Data}

The data for this research are from the Church and Community Planning Inventory (CCPI), ${ }^{2}$ a 1987 survey administered in Indiana and Illinois to 5,123 members of 62 congregations across 11 denominations. ${ }^{3}$ Each denomination submitted a list of its congregations, from which a stratified sample was chosen (i.e., one third rural, one third small cities and suburbs, and one third metropolitan). The project coordinator in conjunction with denominational leaders chose these "typical" congregations (see Dudley 1991). The congregations range in size from 47 to more than 2,000 members. The CCPI sampled between 14 and 222 members in each congregation. Random sampling procedures were used in congregations with more than 250 members. The respondents completed a self-report mail survey. About one-third of the prospective congregations declined, many citing a lack of interest in the overall project on the part of lay leaders. The average response rate within participating congregations was 55 percent. The CCPI data are applicable to this research because they contain data at both the individual and congregational levels in addition to measures of conservative ideology, church participation, and civic participation. It is important to note that this is a sample of church members, not a sample of the general population.

\section{Dependent Variable}

The dependent variable in the following analyses is the number of nonchurch organizations to which the respondents belong, coded zero for none to four for four or more. ${ }^{4}$ Seventy percent of the CCPI respondents belong to at least one nonchurch organization. ${ }^{5}$ The nonchurch organizations variable is a measure of general civic participation. This variable is a previously established proxy for civic participation and engagement with secular society (McIntosh and Alston 1982).

\section{Measures Of Conservative Christianity}

Conservative Christianity, measured through conservative theology and within-congregation social ties, is hypothesized to decrease civic participation. Individual view of the Bible and mean congregational view of the Bible are used as measures of conservative theology. The congregational measure is simply an average of the individual responses in the congregation, and it 
gauges the context of conservative theology. View of the Bible is coded from one for respondents who believe the Bible is a valuable book written by wise men (i.e., theologically most liberal) to four for those respondents who believe the Bible is the actual word of God to be taken literally (i.e., theologically most conservative). ${ }^{6}$ While a single measure cannot capture an entire theological outlook (Woodberry and Smith 1998), biblical literalism is recognized as a proxy for Christian theology (see Kellstedt and Smidt 1993).

Conservative congregations tend to have higher rates of internal friendships and withinchurch social ties than other congregations (Demerath 1965; Iannaccone 1994). Where there are more social ties in an organization, there is presumably less activity outside of the organization. The number of five closest friends belonging to the respondent's church is the indicator of withinchurch social ties, coded from zero for none of their closest friends belonging to their church to five for all five of their closest friends belonging to their church. Both individual respondents' numbers of church friends and the mean congregational number of church friends are included in the analysis. At the individual level, number of friends in church and biblical literalism are positively correlated at 0.065 , meaning more conservative church members also have more friends in their churches. At the congregational level, biblical literalism and number of friends in church are positively correlated at 0.252 , demonstrating that theologically conservative churches have considerably more within-church social ties than do theologically liberal churches.

\section{Church Participation Measures}

In addition to the proposed negative effects of conservative Christianity on civic activity, this article explores the likely positive effects of church participation on civic participation. Church participation is measured through church attendance and number of church organization memberships, both individual responses to these questions and the mean congregational responses. Congregational measures of church participation are, in a sense, control variables, ensuring that the effects of congregational-level within-church friendships and biblical literalism are not confounded with the effects of active or inactive churches. Church attendance is coded from one for church members who say they never attend church to seven for those who say they attend every day. Number of church organization memberships is coded the same as the dependent variable, number of nonchurch organization memberships, from one for one membership to four for four or more memberships. While some research shows that church attendance is positively related to civic activity, there is reason to believe that church attendance is often acting as a proxy for involvement in church organizations where members participate in activities and learn skills that are easily translatable to nonchurch organizational involvement. In other words, with the introduction of the measure of membership in church organizations, church attendance may not be related to civic activity or may even be negatively related to civic activity (Brown and Brown 2003; Lam 2002; Park and Smith 2000).

\section{Denominational Affiliation Measures}

Comparing the effects of the congregational context with the effects of denominational affiliation on civic participation is a primary goal of this article. As mentioned earlier, it is possible that denominational affiliation is often acting as a proxy for the congregational context. Denominational dummy variables test for denominational differences in nonchurch organization memberships. Catholic is the reference category, so each dummy variable refers to the difference between that denomination and Catholics in membership in nonchurch organizations.

\section{Control Variables}

Eight control variables are included in the analyses. The control variables are correlates of membership in voluntary organizations and various aspects of religion and, therefore, they may 
bias the results if not included in the analysis (Verba, Schlozman, and Brady 1995). Education is coded one for those without a high school degree up to six for those with a postgraduate degree. Family income is coded in $\$ 10,000$ increments from one for those who earn $\$ 9,999$ or less to seven for those who earn $\$ 60,000$ or more..$^{7}$ Community size is coded one for those who live in the "midtown" of a large city up to nine for those who live in a "rural village." Sex is coded one for males and two for females. Age is coded in years of age. Race is a dummy variable indicating African-American respondents. Marital status is coded one for single respondents and two for married respondents. Finally, a variable indicating the absence of children is coded one for respondents who have a child under the age of 18 living in their home and two for those who have no children in their home.

\section{Methodology}

I use multilevel models to analyze the effects of individual factors, congregational factors, and denominational affiliation on membership in nonchurch organizations. Each model is a twolevel model that analyzes the effects of individual and congregational variables on membership in nonchurch organizations, as well as allowing for the decomposition of individual and congregational variation in membership in nonchurch organizations. Denominational effects can be analyzed at the congregational level since denominational affiliation does not vary within each congregation. ${ }^{8}$ With nested data and multilevel modeling the different levels (i.e., individual and congregational) are assigned a submodel within a larger model designating the relationship between the independent variables and number of nonchurch organization memberships (Bryk and Raudenbush 1992). ${ }^{9}$ Only with nested data can the specific levels be empirically separated and modeled in a multilevel fashion, enabling a comparison between the effects of individual and congregational factors. Everyday regression techniques, such as ordinary least squares, are unable to separate the various levels, resulting in pooled measures that cannot delineate the precise origins of the relationships in question. Multilevel models, on the other hand, correct for multicollinearity between the different levels by allowing dependency to be modeled separately between groups and between cases within the same group (Bryk and Raudenbush 1992; Kreft and De Leeuw 1998).

Four two-level models examine the religious factors associated with membership in nonchurch organizations. ${ }^{10}$ The first model explores the effects of individual-level demographic factors on membership in nonchurch organizations. The second model adds individual-level religious factors to the equation. The third model adds denominational affiliation. The fourth and final model adds congregational factors to the equation. Comparisons among the models in addition to the proportional effects of the different variables in the final model should help clarify the effects of religion on civic participation. The fourth model, a full model, is as follows:

Membership in nonchurch organizations $=\beta^{0}+\beta^{1}$ (view of the Bible)

$+\beta^{2}$ (number of church friends) $+\beta^{3}$ (number of church organizations)

$+\beta^{4}$ (church attendance) $+\beta^{5}$ (community size $)+\beta^{6}($ sex $)+\beta^{7}$ (age $)+\beta^{8}$ (race)

$+\beta^{9}$ (marital status $)+\beta^{10}$ (no children $)+\beta^{11}$ (income $)+\beta^{12}$ (education $)+R$

$\beta^{0}=\gamma^{00}+\gamma^{01}$ (congregational view of the Bible)

$+\gamma^{02}$ (congregational number of church friends)

$+\gamma^{03}$ (congregational number of church organizations)

$+\gamma^{04}$ (congregational church attendance $)+\gamma^{05}$ (American Baptist $)+\gamma^{06}$ (AME Zion)

$+\gamma^{07}($ Brethren $)+\gamma^{08}$ (Disciples of Christ $)+\gamma^{09}($ ELCA $)+\gamma^{010}$ (Evangelical Covenant $)$

$+\gamma^{011}$ (Presbyterian USA $)+\gamma^{012}$ (Southern Baptist $)+\gamma^{013}$ (UCC)

$+\gamma^{014}$ (United Methodist) $+U^{0}$ 
$R$ is a level-one error term or variance component and $U^{0}$ is a level-two error term or variance component.

\section{Results}

Given that the main point of this article is that congregations affect their members' civic activities, the first step is to discern the amount of variation in membership in nonchurch organizations that is at the congregational level. Table 1 presents variance components from a null model of membership in nonchurch organizations (i.e., no independent variables). The variance components in the null model divide the total variation into individual and congregational variation. The null model shows that 92 percent of the variation in membership in nonchurch organizations is at the individual level and 8 percent is at the congregational level. Although the vast majority of the variation is at the individual level, 8 percent of the variation at the congregational level represents a fairly large and significant amount of variation between congregations in the number of nonchurch organizations their members belong to. The congregation appears to be a meaningful unit of analysis in analyzing church members' participation in nonchurch organizations, though it remains to be seen what aspects of the congregation are correlated with membership in nonchurch organizations.

Table 2 presents results from four models investigating individual and congregational variations in membership in nonchurch organizations. The first model shows that age, sex, income, and education are all significantly related to holding memberships in nonchurch organizations. Older church members belong to more nonchurch organizations than do younger church members. Men belong to more nonchurch organizations than do women. The social status variables are more strongly correlated with civic activity than the other variables in the first model. High income and especially highly educated church members are far more participatory in nonchurch organizations than are poorer and less educated church members.

The second model adds individual-level religious factors. As hypothesized, church members with more literal views of the Bible belong to fewer nonchurch organizations than those with less literal views of the Bible, though the relationship is not very strong. Church attendance is also moderately and negatively related to membership in nonchurch organizations. In line with previous research, church attendance has a negative effect on civic activity once other forms of church activity, which are more social-capital and civic-skill intensive, are entered into the model (Brown and Brown 2003; Lam 2002; Park and Smith 2000). Unlike church attendance, membership in church organizations has a very strong and positive effect on membership in nonchurch organizations. On the five-point scale of membership in nonchurch organizations, church members who belong to four or more church organizations score one and a fifth points higher than church members who do not belong to any church organizations (i.e., on average, they belong to at least 1.2 more nonchurch organizations).

The third model adds denominational affiliation to the equation, comparing the effects of the two standard measures of religion - individual beliefs and denominational affiliation - on civic activity. Even after controlling for individual factors, members of the 11 Christian denominations in the CCPI data do differ in their level of civic activity, albeit moderately so. Members of the Southern Baptist Convention, the Evangelical Covenant Church, and the Evangelical Lutheran

Table 1. Variation in Number of Nonchurch Organization Memberships

\begin{tabular}{lccr}
\hline & Variance Component & Percent of Total Variation & $N$ \\
\hline Individual $(\mathrm{R})$ & 1.895 & 92 & 5,123 \\
Congregational $\left(\mathrm{U}_{0}\right)$ & $0.163^{*}$ & 8 & 62 \\
\hline
\end{tabular}

${ }^{*} p<0.001$ (there is no significance test for the level-one variation). 
Table 2. Individual and Congregational Effects on Membership in Nonchurch Organizations

\begin{tabular}{|c|c|c|c|c|}
\hline & Model 1 & Model 2 & Model 3 & Model 4 \\
\hline \multicolumn{5}{|l|}{ Congregation } \\
\hline Mean view of Bible & - & - & - & $-0.612 /-0.099^{*}$ \\
\hline Mean no. of church friends & - & - & - & $-0.143 /-0.100^{*}$ \\
\hline Mean no. of church organizati & ions & - & - & $-0.098 /-0.029$ \\
\hline Mean church attendance & - & - & - & $0.069 / 0.017$ \\
\hline American Baptist & - & - & $-0.116 /-0.018$ & $0.112 / 0.017$ \\
\hline AME Zion & - & - & $-0.394 /-.036$ & $-0.147 /-0.013$ \\
\hline Brethren & - & - & $0.054 / 0.007$ & $-0.048 /-0.006$ \\
\hline Disciples of Christ & - & - & $-0.046 /-0.010$ & $0.013 / 0.003$ \\
\hline ELCA & - & - & $-0.289 /-0.055^{*}$ & $-0.121 /-0.023$ \\
\hline Evangelical Covenant & - & - & $-0.440 /-0.083^{* *}$ & $-0.070 /-0.013$ \\
\hline Presbyterian (USA) & - & - & $0.141 / 0.036$ & $0.151 / 0.039$ \\
\hline Southern Baptist & - & - & $-0.421 /-0.053^{*}$ & $-0.178 /-0.022$ \\
\hline UCC & - & - & $-0.085 /-0.016$ & $-0.155 /-0.029$ \\
\hline $\begin{array}{l}\text { United Methodist } \\
\text { (Catholic reference) }\end{array}$ & - & - & $-0.023 /-0.006$ & $0.159 / 0.045$ \\
\hline \multicolumn{5}{|l|}{ Individual } \\
\hline View of Bible & - & $-0.065 /-0.032^{*}$ & $-0.056 /-0.028^{*}$ & $-0.049 /-0.024+$ \\
\hline No. of church friends & - & $-0.021 /-0.026+$ & $-0.019 /-0.023$ & $-0.016 /-0.020$ \\
\hline No. of church organizations & - & $0.250 / 0.227^{* * *}$ & $0.249 / 0.226^{* * *}$ & $0.249 / 0.226^{* * *}$ \\
\hline Church attendance & - & $-0.040 /-0.031^{*}$ & $-0.038 /-0.029^{*}$ & $-0.036 /-0.028^{*}$ \\
\hline Community size & $0.028 / 0.041$ & $0.026 / 0.038$ & $0.015 / 0.022$ & $0.036 / 0.052^{*}$ \\
\hline Sex & $-0.202 /-0.068^{* * *}$ & $-0.244 /-0.082^{* * *}$ & $-0.247 /-0.083^{* * *}$ & $-0.247 /-0.083^{* * *}$ \\
\hline Age & $0.004 / 0.047^{* *}$ & $0.003 / 0.042^{* *}$ & $0.003 / 0.035^{*}$ & $0.003 / 0.036^{*}$ \\
\hline Race & $-0.074 /-0.016$ & $-0.068 /-0.014$ & $0.049 / 0.010$ & $0.031 / 0.007$ \\
\hline Marital status & $-0.075 /-0.024$ & $-0.084 /-0.027+$ & $-0.083 /-0.026+$ & $-0.082 /-0.026+$ \\
\hline No. of children at home & $0.057 / 0.019$ & $0.089 / 0.029+$ & $0.086 / 0.028+$ & $0.083 / 0.027+$ \\
\hline Income & $0.078 / 0.099^{* * *}$ & $0.076 / 0.096^{* * *}$ & $0.073 / 0.092^{* * *}$ & $0.072 / 0.091^{* * *}$ \\
\hline Education & $0.264 / 0.283^{* * *}$ & $0.225 / 0.240^{* * *}$ & $0.223 / 0.239^{* * *}$ & $0.220 / 0.235^{* * *}$ \\
\hline Intercept & 1.597 & 1.585 & 1.582 & 1.572 \\
\hline Individual $R^{2}$ & 0.089 & 0.133 & 0.133 & 0.134 \\
\hline Congregational $R^{2}$ & 0.651 & 0.686 & 0.780 & 0.842 \\
\hline
\end{tabular}

Significance: $+p<0.1,{ }^{*} p<0.05,{ }^{* *} p<0.01,{ }^{* * *} p<0.001$

Individual (level 1) $N=5,123$.

Congregation (level 2) $N=62$.

Table reports the regression coefficient/standardized regression coefficient.

Church of America belong to fewer nonchurch organizations than Catholics. The addition of denominational affiliation slightly reduces the negative effects of biblical literalism, though view of the Bible remains a moderate and significant predictor. Education and membership in church or- 
ganizations continue to have the strongest effects on membership in nonchurch organizations in the third model.

The fourth and final model considers the role of congregational factors, in addition to individual factors and denominational affiliation, in affecting civic activity. Both congregational measures affiliated with conservative churches - mean congregational view of the Bible and mean number of five closest friends in the congregation - are strongly and negatively related to membership in nonchurch organizations. The congregational level indicators of church participation, on the other hand, do not have any meaningful effect on membership in nonchurch organizations. Only individual church members' education and number of church organization memberships have stronger effects than congregational view of the Bible and congregational number of church friends. On the five-point scale of number of nonchurch organization memberships, members of congregations with the most literal mean view of the Bible score about 0.7 lower than members of congregations with the least literal mean view of the Bible. Additionally, members of churches with the highest mean number of friends in the same church score about 0.4 lower than members of churches with the least mean number of friends in the same church. Overall, the full model explains about 20 percent of the total variation in the number of nonchurch organization memberships (more than 13 percent of the individual-level variation and more than 84 percent of the congregational-level variation). The congregational measures of conservative theology and within-church social ties, together with individual-level social status and number of church organization memberships, have substantial effects on church members' participation in nonchurch organizations.

\section{Discussion}

As much previous research demonstrates, religion affects civic activity. This article contributes to knowledge on the subject by further clarifying which aspects of religion affect church members' civic activity and at what levels, organizational or individual, these relationships exist. Religious activity, as the social capital and civic participation literature often notes, is positively correlated with activity in nonchurch organizations. Simply attending church, however, does not seem to supply the knowledge or skills that translate into secular organizational activity. Instead, participation in church organizations strongly predicts civic activity. As researchers focusing on civic skills point out, it may take participation in activities that can build leadership, public speaking, and administrative skills to affect civic activity (Verba, Schlozman, and Brady 1995). The congregational measures of church participation do not meaningfully affect civic activity while the individual measure of participation in church organizations has a very strong, positive effect on civic activity (supporting the second hypothesis). The relationship between church members' church activity and civic activity appears to be primarily an individual-level relationship.

The effects of conservative theology on civic participation, unlike religious participation, work at the congregational and individual levels. Church members with literal views of the Bible are moderately less likely than church members with liberal views of biblical literalism to belong to nonchurch organizations. At the congregational level, biblical literalism is strongly and negatively related to civic activity. It is important to note that conservative churches may encourage evangelistic voluntary activity (Wuthnow 1999). When it comes to secular civic activity, however, the context of conservative theology and to a lesser extent individual conservative theology lead to lower levels of civic participation (providing moderate support to the first hypotheses and strong support for the third hypothesis).

When most close social ties are within the congregation, which is prevalent in conservative churches, there is less secular activity among all members. The negative association between within-church social ties and civic activities is primarily a congregational-level relationship (again, providing strong support for the third hypothesis). Furthermore, the congregational characteris- 
tics associated with conservative theology explain away the denominational effects on civic activity (supporting the fourth hypothesis). The fact that members of churches with many within-church social ties are not likely to participate in nonchurch organizations should not be surprising from the network point of view. In an influential study, Granovetter (1973) points out that more strong or overlapping ties, at the cost of weak ties, lead to less access to information and community organizing. In this case, the strength of ties within the congregation leads to less civic activity.

In general, the negative effects of conservative Christianity on civic participation are largely congregational effects while the positive effects of church activity on civic activity are individuallevel effects. The views of conservative clergy and the attitudes of fellow congregants who are conservative appear to influence church members' civic activities. Presumably, authority and peer influences are absorbed through socialization processes. While the context of conservative Christianity is negatively associated with church members' civic activity, the context of activity within the church has little effect on members' civic activity. This suggests that conservative values may be easily shared and assimilated, influencing members' activity outside of the church, though norms of activity within the congregation do not appear to translate to activity outside of the church.

This article demonstrates that nested data, which contains information on individuals, their congregations, and their denominations, should be the preferred form of data for empirical inquiries into civic activity or other outcomes associated with religion. The Christian religion takes place in a social context, the church; yet church members are still individuals, bringing previously formed ideas with them into the church. Neither individual measures nor institutional measures alone are sufficient. Despite the impediments to the use of nested data, such as the increased costs and the need for advanced statistical techniques, this method of investigation portrays the relationships in question more clearly than a single level of measurement.

Future surveys investigating the relationship between religion and civic activity can improve upon the measures and sample in the CCPI to make the findings presented in this article more generalizable. The current research would greatly benefit from more complete measures of theology. A single measure, such as the view of the Bible measure used in this research, may overlook some important theological aspects (see Kellstedt and Smidt 1993; Woodberry and Smith 1998). Additionally, supplementary measures of civic participation would be beneficial for future research. The sample employed, though it provided the necessary variables, is not ideal. A larger sample of congregations would further validate the findings presented here. A random sample of congregations, a larger sample of denominations, and a national sample would provide greater generalization to the findings and should be pursued in future research. Finally, longitudinal data would add much to this line of research; for instance, though the strong, positive effect of membership in church organizations on civic activity supports much of the social capital literature, without longitudinal data it is impossible to be sure that activity in church organizations provides the information, impetus, or skills necessary for activity in nonchurch organizations.

\section{Conclusions}

From Tocqueville to the present day political researchers have sung the praises of civic participation for the proper functioning of a healthy democratic society (e.g., Paxton 1999; Putnam 1995). Voluntary organizations, or mediating institutions, protect the individual from the state, prevent rampant individualism, and provide services so people are less reliant on state bureaucracies (Leege 1993). Inequalities in civic engagement, however, such as the lack of participation by conservative Christians, create distortions in democratic representation (Verba, Schlozman, and Brady 1995). The views and positions of those who do not participate are underrepresented in the democratic process; lower levels of civic activity lead to political disadvantage. The results from this article suggest that members of churches with a theologically conservative climate and with many within-church social ties are less active in civic organizations, thereby limiting their political power and representation. On the other hand, church members who are active in 
church organizations are also active in civic organizations, thus ensuring their voice in the political arena. It is possible, however, that the politicization of Christianity creates a political voice for conservative Christians despite their lack of interaction with other groups.

Not only can conservative churches limit the political power of their members, but they can also curtail connections between church members and other members of the community, members of the community who can provide them with valuable social, emotional, and physical resources as well as a shared sense of the common good. In other words, though conservative congregations may be conducive to the bonding form of social capital that manifests itself in trust and relationships within the church, they may also limit the bridging form of social capital that connects church members to those outside of the church. Churches are relatively homogeneous organizations (Dougherty 2003; Emerson and Kim 2003; Emerson and Smith 2000). Wood and Warren (2002:9) point out that "[r]elatively homogeneous communities may be more or less well-organized internally, but what appears often missing in American social and political life is much of a bridge across communities." Congregations with theologically conservative atmospheres and with many within-group social ties tend to restrict members' civic activities, possibly limiting the opportunity for these bridges across communities. Connections with people outside of one's own relatively homogonous group make available widely shared social identities, broad channels of information sharing, and extensively accepted norms, which are forms of social capital that provide bases for social action (Coleman 1988). Without these connections with people outside of their congregations, members of conservative churches may be disadvantaging themselves and almost certainly harming the public good by limiting interaction among different segments of American society. Conservative churches can shelter members from public debates by limiting contact between church members and those outside of their churches, thereby preventing members of conservative churches from engaging in an open dialogue with other groups, which can be harmful to the public good in general.

The overriding focus of sociology concerns interactions between individuals and social institutions. Much of religion takes place in such an institution, where parishioners are affected by their social surroundings, their fellow parishioners, and the clergy. Congregational researchers stress how socialization in Christian congregations can bring members' attitudes and actions into conformity with fellow congregation members and the pastor (e.g., Gilbert 1993; Wald, Owen, and Hill 1988, 1989, 1990; White 1968). In particular, sociologists have noted that strong social control mechanisms are prevalent in conservative congregations (Stark and Glock 1965; Wuthnow 1988). This article supports notions of socialization in conservative congregations by demonstrating that members of conservative congregations, where there is a high degree of biblical literalism and withingroup social networks, are less active in nonchurch organizations than are members of more liberal congregations. Conservative congregations appear to influence their members' views of how to interact with secular society as well as how much time their members have to participate in secular activities. Simply put, what is preached from the pulpit and talked about in the pews influences church members' activities, not just in the church but also outside of the church.

\section{Acknowledgments}

The author would like to thank Amy Anderson, Lee Ann Banaszak, Kraig Beyerlein, Roger Finke, John McCarthy, Jennifer McKinney, Hart Nelsen, Wayne Osgood, Jason Schwadel, three anonymous reviewers, and the JSSR editor for their advice and comments on earlier drafts of this article. An earlier version of this article was presented at the 2002 American Sociological Association meeting.

\section{Notes}

1. Note that church effects may reflect selection effects, meaning like-minded people choose to attend certain types of churches instead of churches affecting the members' viewpoints and activities. While this is not likely to be the sole reason for congregational effects, a longitudinal study is needed to parcel out selection effects from contextual effects. 
2. The Lilly Endowment, Inc. and McCormick Theological Seminary funded the CCPI. The principal investigator was Carl S. Dudley. The original aim of the project was to study Christian church members' attitudes on church life. The results of the CCPI were primarily intended to help develop church programs. For more information on the CCPI, see Dudley (1991). The data were supplied, free of charge, by the American Religion Data Archive: http://www.TheArda.com

3. The denominations were chosen to represent the full spectrum of mainstream American Christianity. In total, there are 10 Roman Catholic, 5 Evangelical Covenant, 2 Southern Baptist, 5 United Church of Christ, 5 Evangelical Lutheran Church in America, 1 AME Zion, 12 United Methodist, 10 Presbyterian Church (U.S.A.), 7 Disciples of Christ, 3 American Baptist, and 2 Brethren congregations.

4. The nonchurch organizations question reads: "To how many organizations, other than church organizations, do you belong?"

5. Thirty percent of respondents belong to no nonchurch organizations, 22 percent belong to one organization, 19 percent belong to two organizations, 12 percent belong to three organizations, and 16 percent belong to four or more organizations.

6. The view of the Bible question reads: "Which of the following statements best expresses your view of the Bible?" The response categories are: "1) The Bible is a valuable book because it was written by wise and good people, but I do not believe it is really God's word ... 2) The Bible is a record of many different people's response to God and because of this, people and churches today are forced to interpret for themselves the Bible's moral and religious teachings ... 3) The Bible is the inspired Word of God and its basic moral and religious teachings are clear and true, even if it does contain some human error ... 4) The Bible is the actual Word of God and is to be taken literally." While a biblical literalism question cannot represent an entire theological outlook, this version is a better proxy for conservative theology than other versions that offer more limited response categories.

7. The correlation between education and income is 0.383 , far from the level of multicollinearity that would cause methodological problems.

8. A thorough comparison of individual, congregational, and denominational effects would ideally be a threelevel model, with individuals nested in congregations that are nested in denominations. Unfortunately, proper three-level data are not available. Nonetheless, the two-level model presented here tests for denominational effects without methodological problems. Denominational affiliation can be tested at the congregational level since it does not vary within congregations, though the proportion of the total variation at the denominational level cannot be ascertained, as it could be in a three-level model. Three-level data would require more level-three units (i.e. denominations) as well as more congregations within each denomination.

9. The independent variables are grand mean centered in all models, so the congregational and denominational effects are context effects above and beyond individual variations. Data are deleted pairwise in all regressions.

10. The models are linear HLM models, given that the dependent variable, membership in nonchurch organizations, is a fairly evenly distributed five-category variable. Ordinal HLM models mirroring the models presented here show no significant differences, the results are the same as the linear regressions presented in this article, and tests for curvilinear relationships did not detect such a relationship.

\section{References}

Ammerman, N. T. 2000. New life for denominationalism. Christian Century March, 15:312-407.

Brown, R. K. and R. E. Brown. 2003. Faith and works: Church-based social capital resources and African-American political activism. Social Forces 82(2):617-41.

Bryk, A. S. and S.W. Raudenbush. 1992. Hierarchical Linear Models: Applications and Data Analysis Methods. Newbury Park: Sage Publications.

Campbell, D. E. 2004. Acts of faith: Churches and political engagement. Political Behavior 26(2):155-80.

Casanova, J. 1994. Public Religions in the Modern World. Chicago: University of Chicago Press.

Coleman, J. S. 1988. Social capital in the creation of human capital. American Journal of Sociology 94(S):S95-120.

Demerath, N. J., III. 1965. Social Class in American Protestantism. Chicago: Rand McNally \& Company.

Dougherty, K. D. 2003. How monochromatic is church membership? Racial-ethnic diversity in religious communities. Sociology of Religion 64(1):65-85.

Dudley, C. S. 1991. From typical church to social ministry: A study of the elements which mobilize congregations. Review of Religious Research 32(3):195-212.

Emerson, M. O. and K. C. Kim. 2003. Multiracial congregations: An analysis of their development and a typology. Journal for the Scientific Study of Religion 42(2):217-27.

Emerson, M. O. and C. Smith. 2000. Divided by Faith: Evangelical Religion and the Problem of Race in America. New York: Oxford University Press.

Finke, R. and R. Stark. 1992. The Churching of America, 1776-1990. New Brunswick, NJ: Rutgers University Press. 
Gilbert, C. P. 1993. The Impact of Churches on Political Behavior. Connecticut: Greenwood Press.

Granovetter, M. S. 1973. The strength of weak ties. American Journal of Sociology 78(6):1360-80.

Iannaccone, L. R. 1988. A formal model of church and sect. American Journal of Sociology 94S:S241-68.

Iannaccone, L. R. 1994. Why strict churches are strong. American Journal of Sociology 99(5):1180-1211.

Jelen, T. G. 1993. The political consequences of religious group attitudes. Journal of Politics 55(1):178-90.

Kanagy, C. L. 1992. Social action, evangelicalism, and ecumenism: The impact of community, theological, and church structural variables. Review of Religious Research 34(1):34-50.

Kellstedt, L. A. and C. E. Smidt. 1993. Doctrinal beliefs and political behavior: Views of the Bible. In Rediscovering the Religious Factor in American Politics, edited by D. C. Leege and L. A. Kellstedt. New York: M. E. Sharpe.

Klandermans, B. and D. Oegama. 1987. Potentials, networks, motivations, and barriers: Steps towards participation in social movements. American Sociological Review 52(4):519-31.

Kreft, I. and J. D. Leeuw. 1998. Introducing Multilevel Modeling. London: Thousand Oaks.

Lam, P. Y. 2002. As the flocks gather: How religion affects voluntary association participation. Journal for the Scientific Study of Religion 41(3):405-22.

Leege, D. C. 1993. Religion and politics in theoretical perspective. In Rediscovering the Religious Factor in American Politics, edited by D. C. Leege and L. A. Kellstedt. Armonk, NY: M.E. Sharpe.

Lenski, G. 1963. The Religious Factor: A Sociologist's Inquiry. Garden City, NY: Anchor Books.

Marx, G. T. 1967. Religion: Opiate or inspiration of civil rights militancy among Negroes? American Sociological Review 32(1):64-72.

McAdam, D. and R. Paulsen. 1993. Specifying the relationship between social ties and activism. American Journal of Sociology 99:640-67.

McIntosh, W. A. and J. P. Alston. 1982. Lenski revisited: The linkage role of religion in primary and secondary groups. American Journal of Sociology 87(4):852-82.

McPherson, M. and T. Rotolo. 1996. Testing a dynamic model of social composition: Diversity and change in voluntary groups. American Sociological Review 61:179-202.

McPherson, M., L. Smith-Lovin, and J. M. Cook. 2001. Birds of a feather: Homophily in social networks. Annual Review of Sociology 27:415-44.

Niebuhr, H. R. 1929. The Social Sources of Denominationalism. Gloucester, MA: Peter Smith.

Park, J. Z. and C. Smith. 2000. "To whom much has been given ..." Religious capital and community voluntarism among churchgoing protestants. Journal for the Scientific Study of Religion 39(3):272-86.

Paxton, P. 1999. Is social capital declining in the United States? A multiple indicator assessment. American Journal of Sociology 105(1):88-127.

Pope, L. 1942. Millhands and Preachers. New Haven, CT: Yale University Press.

Popielarz, P. A. 1999. Organizational constraints on personal network formation. Research in the Sociology of Organizations 16:263-81.

Putnam, R. D. 1995. Bowling alone: America's declining social capital. Current 373:3-9.

Regnerus, M. D. and C. Smith. 1998. Selective deprivation among American religious traditions: The reversal of the great reversal. Social Forces 76(4):1347-72.

Schwadel, P. 2002. Testing the promise of the churches: Income inequality in the opportunity to learn civic skills in church. Journal for the Scientific Study of Religion 41(3):563-73.

Smidt, C. 1998. American Evangelicals: Embattled and Thriving. Chicago: University of Chicago Press.

Smidt, C. 1999. Religion and civic engagement: A comparative analysis. Annals of the American Academy of Political and Social Science 565:176-92.

Stark, R. and C. Y. Glock. 1965. Religion and Society in Tension. Chicago: Rand McNally.

Steensland, B., J. Z. Park, M. D. Regnerus, L. D. Robinson, W. B. Wilcox, and R. D. Woodberry. 2001. The measure of American religion: Toward improving the state-of-the-art. Social Forces 79(1):291-318.

Verba, S., K. L. Schlozman, and H. E. Brady. 1995. Voice and Equality: Civic Voluntarism in American Politics. Cambridge, MA: Harvard University Press.

Wald, K. D., D. E. Owen, and S. S. Hill, Jr. 1988. Churches as political communities. American Political Science Review 82(2):531-48.

Wald, K. D., D. E. Owen, and S. S. Hill, Jr. 1989. Evangelical politics and status issues. Journal for the Scientific Study of Religion 28(1):1-16.

Wald, K. D., D. E. Owen, and S. S. Hill, Jr. 1990. Political cohesion in churches. Journal of Politics 52(1):197-215.

White, R. H. 1968. Toward a theory of religious influence. Pacific Sociological Review 11(1):23-28.

Wood, R. L. and M. R. Warren. 2002. A different face of faith-based politics: Social capital and community organizing in the public arena. International Journal of Sociology and Social Policy 22(9/10):6-54.

Woodberry, R. D. and C. Smith. 1998. Fundamentalism et al.: Conservative protestants in America. Annual Review of Sociology 24:25-56.

Wuthnow, R. 1988. The Restructuring of American Religion. Princeton, NJ: Princeton University Press.

Wuthnow, R. 1999. Mobilizing civic engagement: The changing impact of religious involvement. In Civic Engagement in American Democracy, edited by T. Skocpol and M. P. Fiorina. New York: Brookings Institution Press. 